\title{
Editorial: Mission Studies in Contact Zones
}

\author{
Norbert Hintersteiner, Sara Fretheim, and Dorottya Nagy \\ Chief Editorial Team, Institute of Missiology and the Study of Theologies \\ Beyond Europe, University of Muenster, Muenster, Germany \\ imw@uni-muenster.de
}

"Mission Studies in Contact Zones." This is the motto with which the new editorial team of this journal has the pleasure to engage you as readers, authors, IAMS members, and members of other missiological networks, since its recent transition to the Institute of Missiology and the Study of Theologies Beyond Europe at the Catholic Theological Faculty of the Westphalian Wilhelm University (wwU) of Muenster, Germany, in January 2021. The new editorial team is comprised of Prof. Dr. Norbert Hintersteiner (Editor-in-Chief), Dr. Sara Fretheim and Prof. Dr. Dorottya Nagy (Assistant Editors), and Ms. Anja Heinz (Editorial Assistant). The editorial team is supported by the ongoing work of Dr. Atola Longkumer (Imphal, Manipur; Book Review Editor), and by Dr. Mariel Deluca Voth (Buenos Aires), and Dr. Xiaoli Yang (Melbourne), who translate article abstracts into Spanish and Chinese. As an international team, we welcome your critical readership and scholarly submissions, your promotion of the journal, ideas for novel themes, and all of your efforts to bring Mission Studies and its readers into new contact zones.

"Mission in contact zones" is also the thematic thread linking the essays in this issue. "Autoethnography, transculturation, critique, collaboration, bilingualism, mediation, parody, denunciation, imaginary dialogue, vernacular expression - these are some of the literate arts of the contact zone. Miscomprehension, incomprehension, dead letters, unread masterpieces, absolute heterogeneity of meaning - these are some of the perils of writing in the contact zone" (Pratt 1991: 37). These are the words of Mary Louise Pratt, Professor of Spanish and Portuguese Languages and Literatures, who, some thirty years ago, introduced the notion of "contact zone," which has now also become part of mission studies vocabulary. Pratt's "contact zone" refers to "social spaces where cultures meet, clash, and grapple with each other, often in the context of highly asymmetrical relations of power, such as colonialism, slavery, or their aftermaths, as they are lived out in many parts of the world today" (Pratt 1991: 34). Pratt's words and this concept fittingly express 
the scope of this journal, which is dedicated to the scholarly study of "contact zones" in which the Christian factor plays an important role. This issue of Mission Studies, divided into two parts, uses a bifocal lens in engaging various "contact zones." In the first part, the first four contributions focus on the missionary as agent and protagonist in the contact zones. The second part includes three articles which are a continuation of last year's special issue on "Locating European Missions in a Wounded World" (37.3), and which elaborate on models of mission and vulnerability required by or emerging from contact zones.

Rafael Gaune and Maria Montt Stabucchi, both based at the Instituto de Historia of the Pontificia Universidad Católica de Chile, challenge the reader to rethink the concept of "missionary" in contact zones, arguing that the missionary as protagonist is a fluid identity marker that depends upon who, when, and under which historical circumstances "the missionary" is being constructed. The missionary in this case is the Jesuit Francis Xavier (1506-52), and the exercise through which Xavier as missionary becomes constructed, deconstructed, and reconstructed is based on the Quito Sermon dated 1741. Through an annotated, detailed, and contextual reading of the sermon, Gaune and Stabucchi argue that during the reception history, Xavier's identity as missionary undergoes a fundamental shift from "being a body tied to pain and relics to a soul that floods the preaching of the Catholic orb," an identity captured in the title as "missionary in the world". They further analyse the construction of the saint in the 16th and 17th centuries and lucidly describe how time and again contextual theological needs and arguments arise from the identity of Xavier as a missionary. The article draws attention to discourses on materiality and immateriality, textuality, and visuality in mission studies.

In her contribution, ELLEN VeA Rosnes explicitly works with the notion of contact zones and illustrates the complex negotiations of the Norwegian Mission Society's missionaries with the multiple agencies in Zululand and Natal during World War II. The article is about negotiating education through the dynamics of negotiating missionary identities: "The Norwegian missionaries found themselves in both subordinate and higher-ranking positions vis-à-vis the actors with whom they negotiated, and this was dependent on the actual interaction." Rosnes' conclusion offers a helpful segue into MARYSE KrUithof's analysis of Elmer Miller's thesis, "The Christian missionary, agent of secularization." Kruithof re-reads Miller's thesis, written half a century ago, through the lens of how the missionary has been seen as an agent of social change in scholarly work, and concludes that the thesis still needs to be tested. Kruithof points to a gap in researching the link between Christian mission and secularization, and frames Miller's thesis in the self-reflexivity of the (in this 
case) deconverted missionary and invites further research on missionaries' vocabulary and their "power" in contact zones.

The fourth contribution in this first part could be perceived as the scholarly self-reflection of a contemporary missionary. Drawing from mission scholarship as well as pastoral experience in New Zealand, MARIo WEYERS describes the process of identity change from "migrant worker" to "missionary" in a contact zone. He does so by working with the Maori concept of Turangawaewae ("a standing place for one's feet"). Through this concept, Weyers leads the reader through a number of missio-theological models and seeks to elaborate upon the complex relationships between the missionary, the people, and the land, and arrives at a pneumatological praxis which makes the identity of the missionary an open-ended narrative.

The second section of this issue contains three articles which had their origins in presentations given at the IAMS Europe Conference $(23 \mathrm{rd}-27$ th August 2019, Sankt Augustin, Germany), and which should be seen as an extension of the resulting special issue entitled "Locating European Missions in a Wounded World in Deep Transformation" (37.3). Concepts such as "wounds" and "vulnerability" were contextually worked out and reflected upon. The conference engaged some of the shadow sides of mission in contact zones and sought to present theological-missiological tools, theories, and models which might help in the translation of theologies and missiologies into Christian mission praxis, practices of reconciliation, and peaceful co-existence. The authors of these three articles are sensitive to the contexts in which their research is located, as they themselves are rooted in those contexts.

IRINA PAERT takes the reader into the complex power relations of a postCommunist setting and uncovers the ways in which Christian churches are protagonists in the negotiations of religious and political powers. She introduces the theology-spirituality of St Sophrony Sakharov (1896-1993) and St Silouan, his spiritual father, and the music of the contemporary composer Arvo Pärt (b. 1935), with the intention of constructing a model for intra-Christian reconciliation in Estonia. Taken as guides towards inter-ethnic, inter-confessional, and inter-generational healing, these saints and this artist together point to the importance of spirituality within any missionary endeavour. Paert argues that "reconciliation is not an outward but inward process that begins and ends in a person's heart"; this is why she argues that music and personal ascesis in following Christ are fundamental for the healing of wounds.

Helene Fisher, Elizabeth lane Miller and Christof Sauer bring us into the field of gender-specific Christian persecution, confronting Christian communities and mission theologies that are complicit in causing these wounds. After giving a broader description of the field, they draw 
parallels between a case study based on a re-reading of Exodus 1 and a case study in complicity from the Central African Republic. The contribution well illustrates the nuances within, and limitations of, relationships in contact zones, and continues to keep "Christian witness" on the agenda of scholarly attention.

Stefan PaAs closes this issue's conversation on contact zones. As one of the keynote speakers at the 2019 IAMs Europe conference, he looks at the question of vulnerability and mission within the "secularized societies of western Europe." Paas writes about a "loss of heart" in missionary presence and connects with Paert's argument on the importance of spirituality in mission. In Paas's understanding, spirituality places the "why" question prior to the "what" and "how" questions. By prioritizing the why question, Paas uses the images of diaspora and exile for describing the context in which Christians in western Europe find themselves, and opts for the notion of priesthood as a missional metaphor central to his missional spirituality. The article connects to the question about the identity of the missionary (priest 1 Pet 2:9) and also touches upon the issue of representation. Paas's arguments for Christian identities as "persons-in-community" and representation as "humans-in-relationship" invite further conversations about agency and mission.

This first issue of a new year brings us to the heart of the complex dynamics of contact zones and encourages the reader to stay engaged in mission studies, contributing to the manifold conversations with his/her/a unique voice.

\section{Reference Cited}

Pratt, Mary Louise (1991). "Arts of the Contact Zone." Profession, 33-40. Accessed October 21, 2020, from http://www.jstor.org/stable/25595469. 